Sedimentary

Research
Journal of Sedimentary Research, 2011, v. 81, 656-669

Research Article

DOI: $10.2110 /$ jsr.2011.51

\title{
USE OF CLUMPED-ISOTOPE THERMOMETRY TO CONSTRAIN THE CRYSTALLIZATION TEMPERATURE OF DIAGENETIC CALCITE
}

\author{
KATHARINE W. HUNTINGTON, ${ }^{1}$ DAVID A. BUDD ${ }^{2}$ BRIAN P. WERNICKE, ${ }^{3}$ AND JOHN M. EILER ${ }^{3}$ \\ ${ }^{1}$ Department of Earth and Space Sciences, University of Washington Seattle, Washington 98195, U.S.A. \\ ${ }^{2}$ Department of Geological Sciences, University of Colorado, Boulder, Colorado 80309, U.S.A. \\ ${ }^{3}$ Division of Geological and Planetary Sciences, California Institute of Technology, Pasadena, California 91125, U.S.A. \\ e-mail:kate1@uw.edu
}

\begin{abstract}
We describe an approach to estimating the crystallization temperatures of diagenetic calcites using clumped-isotope thermometry, a paleothermometer based on the ${ }^{13} \mathrm{C}-{ }^{18} \mathrm{O}$-bond enrichment in carbonates. Application of this thermometer to calcified gastropod shells and calcite cements in an early Eocene limestone from the Colorado Plateau reveals a record of calcite precipitation and replacement at temperatures varying from 14 to $123^{\circ} \mathrm{C}$. The early Eocene host sediments were never deeply buried, but they experienced a significant thermal pulse associated with the emplacement of a late Miocene basalt flow. The combination of independent constraints on thermal history with clumped-isotope thermometry, petrographic (including cathodoluminescence) observations, and oxygen isotopic data provides an improved basis for estimation of the temperature and timing of diagenetic events and fluid sources. The petrography and calcite $\delta^{18} \mathrm{O}$ values, taken alone, suggest that the aragonite-tocalcite transformation of gastropod shell material occurred simultaneously with early formation of cements and lithification of the matrix in the same sample. However, addition of clumped-isotope thermometry demonstrates that this phase transformation of shell material occurred at temperatures of $94-123^{\circ} \mathrm{C}$ in a highly rock-buffered microenvironment (i.e., with the isotopic composition of fluid buffered by coexisting carbonate), millions of years after lithification of the matrix and formation of initial low-temperature $\left(14-19^{\circ} \mathrm{C}\right)$ calcite cements within shell body cavities. Clumped-isotope temperatures in excess of reasonable Earth-surface conditions recorded by later-formed cements demand that cement growth occurred in association with the lava emplacement. Our results illustrate the potential for clumped-isotope thermometry to constrain conditions of diagenesis and guide interpretations that would not be possible on the basis of conventional stable-isotopic and petrographic data alone, and demonstrate how petrographic characterization of clumped-isotope thermometry samples can benefit paleoclimate studies.
\end{abstract}

\section{INTRODUCTION}

The preservation of sedimentary records and evolution of mineral deposits, hydrocarbons, and geothermal reservoirs depend on the thermal and diagenetic histories of rocks in the shallow crust, including the timing, conditions, and duration of fluid flow and the family of reactions that produce diagenetic and metamorphic minerals. Temperatures of diagenesis in sedimentary basins have been inferred using a variety of geochemical and empirical techniques. Common techniques include apatite fission-track and (U-Th)/He thermochronometry (Gleadow et al. 1986; Wolf et al. 1996; Farley 2002; Green et al. 2004), fluid-inclusion microthermometry (Goldstein 2001), oxygen isotope thermometry of coprecipitating phases (Sharp and Kirschner 1994; Richards et al. 2005), vitrinite reflectance (Barker and Pawlewicz 1986), and other organic maturation indices (Tissot et al. 1987). Different tools provide different types of information, constraining rock thermal histories, peak temperatures, or the composition and temperature of coexisting fluids at the time of mineral growth. For this reason and because the applicability of each technique depends on lithology and geologic setting, important information can be gained by integrating complementary approaches and developing new tools.

In this paper we describe the application of carbonate clumped-isotope thermometry (Ghosh et al. 2006a; Eiler 2007) to independently determine the growth temperatures of various generations of primary and diagenetic carbonates and the O-isotopic composition of the waters from which they precipitated. Analysis of a single mineral phase using this thermodynamic technique provides both a precise estimate of the temperature of carbonate mineral growth or recrystallization and the $\delta^{18} \mathrm{O}$ of carbonate, from which estimates of the $\delta^{18} \mathrm{O}$ of diagenetic fluids can be calculated. Measurements of the temperature-dependent clumping of ${ }^{13} \mathrm{C}$ and ${ }^{18} \mathrm{O}$ into a single carbonate ion group (i.e., forming ${ }^{13} \mathrm{C}-{ }^{18} \mathrm{O}$ bonds) in carbonate reveal growth temperatures for texturally distinct calcite phases in a suite of early Eocene limestone samples from the Colorado Plateau that were heated following the emplacement of a Miocene basalt flow. When combined with concurrent measurements of $\delta^{18} \mathrm{O}$ on the same samples, these data permit estimation of $\delta^{18} \mathrm{O}$ of the water in equilibrium with some of the diagenetic calcites, and combined with independent constraints on the samples' temperature-time path and petrographic observations, present an opportunity to reconstruct the samples' postdepositional history in detail.

\section{CARBONATE THERMOMETRY}

Conventional carbonate thermometry is based on the temperature dependence of equilibrium $\mathrm{O}$-isotope fractionation between carbonate 
minerals and the waters from which they precipitate (Urey 1947; McCrea 1950; Epstein et al. 1953). Because this thermometer is based on heterogeneous equilibrium between carbonate and water, the $\delta^{18} \mathrm{O}$ of a carbonate mineral depends on both temperature and the isotopic composition of water, e.g., $\delta^{18} O_{\text {calcite }} \approx \delta^{18} O_{\text {water }}+18.03\left(10^{3} / T\right)+32.42$ (Kim and O'Neil 1997). Thus, conventional $\delta^{18} \mathrm{O}$ thermometry can be applied unambiguously to carbonate minerals only if independent constraints on water isotopic compositions (e.g., Adkins et al. 2003; Kohn et al. 2004) or temperature (e.g., Gawlick and Boehm 2000; Boles et al. 2004; Machel and Buschkuehle 2008) are available, or if there is a strong correlation between $\delta^{18} \mathrm{O}$ of water and temperature, as might be the case for soil carbonates (Cerling 1984).

In contrast, carbonate clumped-isotope thermometry involves homogeneous equilibrium exchange of isotopes among carbonate ions within the solid carbonate phase alone. The technique is based on the temperature dependence of the abundance, relative to a stochastic distribution, of carbonate ion groups that contain both a ${ }^{13} \mathrm{C}$ and an ${ }^{18} \mathrm{O}$ atom (i.e., ${ }^{13} \mathrm{C}^{18} \mathrm{O}^{16} \mathrm{O}_{2}{ }^{2}$ ) (Ghosh et al. 2006a; Eiler 2007). A thermodynamic driving force that increases with decreasing temperature makes it more favorable for ${ }^{13} \mathrm{C}$ and ${ }^{18} \mathrm{O}$ to "clump" into bonds with each other instead of being distributed randomly throughout the crystal lattice (Wang et al. 2004; Schauble et al. 2006). The ${ }^{13} \mathrm{C}^{-18} \mathrm{O}$-bond enrichment can be determined by measuring the $\delta^{18} \mathrm{O}, \delta^{13} \mathrm{C}$, and abundance of mass47 species in $\mathrm{CO}_{2}$ produced by phosphoric acid digestion of carbonate using gas-source isotope ratio mass spectrometry (Eiler and Schauble 2004; Affek and Eiler 2006; Huntington et al. 2009). Mass-47 $\mathrm{CO}_{2}$ species are mostly ${ }^{13} \mathrm{C}^{18} \mathrm{O}^{16} \mathrm{O}$, and their enrichment relative to a stochastic isotopic distribution, denoted as the $\Delta_{47}$ value, depends on carbonate growth temperature.

Most previous applied clumped-isotope thermometry studies have used temperature and $\delta^{18} \mathrm{O}$ of water data for ancient Earth-surface deposits to constrain paleoclimate and landscape evolution (e.g., Ghosh et al. 2006b; Affek et al. 2008; Huntington et al. 2010; Passey et al. 2010), but recent studies of altered fossil shells, carbonatites, and marbles suggest that the thermometer might also be applied to quantify temperatures of diagenesis. Came et al. (2007) applied the clumped-isotope thermometer to Silurian and Middle Pennsylvanian fossil brachiopod and mollusk shells that appeared to be altered by postdepositional processes. The samples recorded temperatures up to $30^{\circ} \mathrm{C}$ warmer than apparently unaltered samples from the same time period, but the authors did not speculate on whether "reset" clumped-isotope temperature records could hold meaningful information regarding the postdepositional history of their samples. Analyses of carbonatites and calcite that has undergone high-temperature recrystallization followed by slow cooling suggests that $\Delta_{47}$ signals do not re-equilibrate over geological timescales (i.e., $10^{8}$ years) below $\sim 250-300^{\circ} \mathrm{C}$ (Ghosh et al. 2006a; Dennis and Schrag 2010; Schmid and Bernasconi 2010). Thus we might expect clumped-isotope thermometry to reflect episodes of diagenetic crystal growth and recrystallization below $\sim 250^{\circ} \mathrm{C}$ with high fidelity. Additionally, there is no dependence of $\Delta_{47}$ values on the $\delta^{18} \mathrm{O}$ of water from which carbonate minerals initially formed. Thus, unlike conventional carbonate-water isotopic thermometers (e.g., Urey 1947), clumped-isotope thermometry yields temperatures of calcite formation in settings for which $\delta^{18} \mathrm{O}$ of diagenetic waters is unknown.

\section{DEPOSITIONAL SETTING AND SAMPLE CHARACTERIZATION}

Fossiliferous freshwater limestone from the Paleogene Music Mountain Formation (Young 1999) was sampled at a locality known as Duff Brown Tank, $50 \mathrm{~km}$ south of Grand Canyon near Long Point, Arizona $\left(35^{\circ}\right.$ $36.48^{\prime} \mathrm{N}, 112^{\circ} 26.27^{\prime} \mathrm{W}$ ) (Fig. 1). The Music Mountain Formation comprises predominantly silt- to sand-dominated arkosic sediments and scattered gravels shed from sources south and west of the modern
Colorado Plateau that represent fluvial and shallow lacustrine deposition in paleocanyons or structural depressions along the southwestern margin of the Plateau (Elston and Young 1991; Young 1999; Young 2001). The arkosic sediments near Long Point contain interbedded fossiliferous lacustrine limestones bearing viviparid gastropods of early Eocene age (Hartman 1984; Hartman and Young 2010) that crop out in small exposures in an escarpment over an approximately 18 -km-wide east-west area (Young 2001). Sediments of the Music Mountain Formation at Duff Brown Tank disconformably overly the Triassic Moenkopi Formation, and in turn are overlain disconformably by a single finely crystalline alkali-olivine basalt flow ranging in thickness from 8 to $92 \mathrm{~m}$, and dated by ${ }^{40} \mathrm{Ar} /{ }^{39} \mathrm{Ar}$ geochronology at $6.76 \pm 0.13 \mathrm{Ma}$ (Peters 2002; Billingsley et al. 2006).

Samples were collected from a $15-\mathrm{cm}$-thick limestone bed $36 \mathrm{~m}$ beneath the basalt (Fig. 1). They contain shells of viviparid gastropods up to $2.5 \mathrm{~cm}$ in diameter with infilling coarse calcite spar (ca. 0.25 to $0.75 \mathrm{~mm}$ ) and microspar in a sparsely fossiliferous peloidal limestone matrix. Open voids are preserved in each of the samples, as matrix and cement have not infilled the gastropod chambers completely. Thin sections of samples were examined with polarized light microscopy and cold-cathodoluminescence (CL) microscopy, the latter performed using a Technosyn Luminoscope operated at $12-15 \mathrm{kV}, 650-550 \mu \mathrm{A}$, and 0.05 torr pressure.

Previously, $\Delta_{47}$ data were reported for three samples from the same locality that included sparry calcite cement (DB4-1), microspar matrix calcite (DB4-2), and calcified gastropod shell (DB4-3) (Huntington et al. 2010). The data indicated temperatures in excess of typical Earth-surface conditions; however, details of the sample context and textures were not presented and no interpretation of the results was offered except the speculation that the samples may have experienced reheating due to emplacement of the nearby basalt flow (Huntington et al. 2010).

A transverse cross section through one of the large gastropod shells and images of the matrix that typify the specimens are shown in Figure 2. Both large, intact shells of adult gastropods and fragmented shells that could be the result of predation or physical abrasion and transport occur in the samples. The gastropod shell fragments range down to coarse silt in size, the thinnest of which probably correspond to juveniles. The brownish color of the shells in thin section delineates growth banding and likely reflects organic remnants. The cross-lamellar microstructure of the originally aragonite shell of the viviparidae is preserved (Figs. 2B, 3). The peloidal matrix surrounds and partially fills each of the gastropod shells. In at least one case, the outer growth layers of a complete gastropod shell are truncated, indicating some post-mortem abrasion. Fractured gastropod fragments (Fig. 2C) indicate mechanical compaction of the sediment.

Equant calcite cement partially fills the gastropod shell cavities. An initial rim of very fine spar (ca. $15 \mu \mathrm{m}$ wide) along the shell wall evolves gradually towards the interior of the shell cavity to a fine crystalline spar (up to $100 \mu \mathrm{m}$ ), and then passes abruptly to coarse crystalline spar (300$750 \mu \mathrm{m})$ (Figs. 2E-F, 4). A consistent growth stratigraphy visible in CL microscopy crosscuts individual crystals in this cement fill (Figs. 3, 4), indicating that the cements grew over a period of time from waters that exhibited temporal variations in $\mathrm{Mn}$ and $\mathrm{Fe}$ content due to variations in oxidation state and/or supply of those cations (Marshall 1988; Machel et al. 1991). The sequence includes six CL cement zones: (1) initial very fineand fine-crystalline spar that is nonluminescent; (2) thin band of orange luminescent calcite overgrowth approximately corresponding to the transition between $<100 \mu \mathrm{m}$ and 300-750 $\mu \mathrm{m}$ crystalline spar; (3) nonluminescent calcite; (4) narrow band of bright orange luminescent calcite; (5) thick zone of nonluminescent calcite corresponding to coarse crystalline spar; (6) broad zone of bright-luminescent calcite found in the center of the pore-filling mosaic. This sequence, or a portion of the sequence, also is found in shell microcracks (Figs. 2, 3) and in biomold 


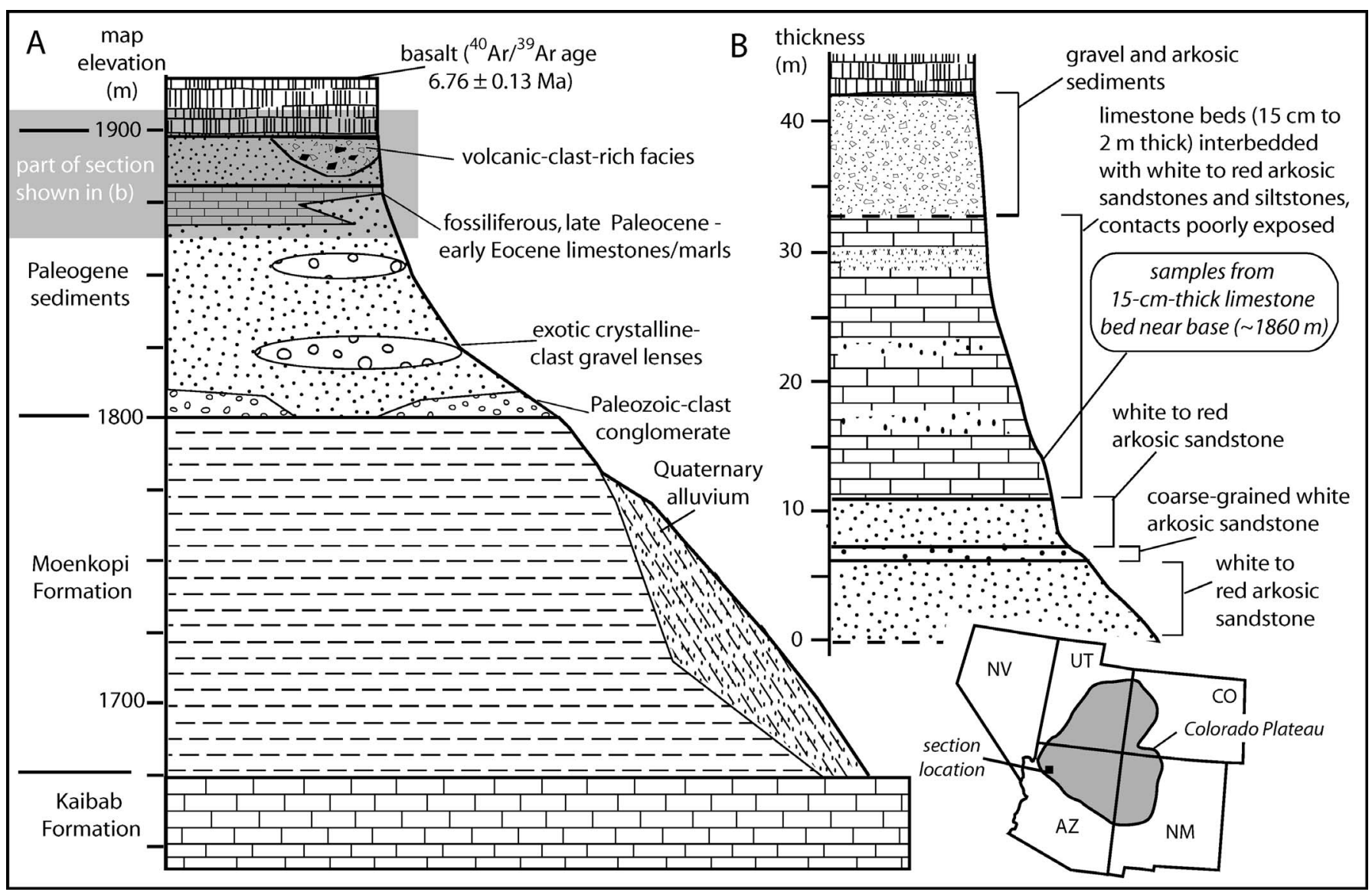

FIG. 1. - Sample locations. A) Section adapted from Young (2001). Recent ${ }^{40} \mathrm{Ar} /{ }^{39} \mathrm{Ar}$ analysis confirmed a date of $6.76 \pm 0.13$ Ma for the single capping basalt (Billingsley et al. 2006). B) Detail of area in gray box in Part A. Sample location: $35^{\circ} 36.48^{\prime} \mathrm{N}, 112^{\circ} 36.27^{\prime} \mathrm{W}$.

fills, irregular spar cement voids, and pores between peloids within the matrix (Fig. 5).

The limestone matrix is polygenetic, containing micrite, peloids, skeletal fragments, and equant calcite spar cement (Figs. 2C, 5), which vary in $\mathrm{CL}$ from nonluminescent to bright orange. Both silt-size and sand-size peloids are present, and are probably fecal in origin. Original interparticle pores between peloids are now filled with spar cement that is dominantly nonluminescent (Fig. 5). The micrite exhibits dull red to bright orange luminescence (Fig. 5), as do silt-size skeletal fragments of gastropods, ostracodes, charophytes, and materials of indeterminate origin. It is unknown if the bright orange luminescence reflects $\mathrm{Mn}$ content at the time of deposition and/or equivalence to CL cement zones 4 or 6 .

Irregular, discontinuous spar-filled voids in the matrix form a rectilinear pattern, and may be the result of early compaction or desiccation, or pedogenic features (Fig. 6). The irregular voids exhibit multiple CL cement zones (Fig. 5D), indicating that they took longer to heal than other void spaces in the matrix. Lack of pellet compaction in the matrix (Fig. 2C, D) and the presence of an intraclast of peloidal matrix within one of the gastropod's intraparticle pores support early lithification.

\section{SAMPLING METHODS AND MINERALOGY}

Shell, cement, and micritic matrix were sampled for Fourier transform infrared (FTIR) spectrometry and clumped-isotope thermometry. Carbonate was collected from fresh interior surfaces of the samples and ground gently into fine powder using an agate mortar and pestle prior to analysis. Samples designated DB4 were collected from the same hand sample as the DB4 samples presented in Huntington et al. (2010) in an attempt to isolate aliquots of carbonate corresponding to specific, texturally simple locations that were characterized in thin section and CL.

Although it was not possible to sample individual gastropod-shell growth bands because of the large quantity of carbonate required for precise $\Delta_{47}$ measurements ( $\sim 8 \mathrm{mg}$ per analysis), shell sampling was limited to narrow growth-band-parallel regions (Fig. 2A). Before obtaining shell material for analysis, a razor was used to remove the outer $\sim 1 \mathrm{~mm}$ of shell from an $\sim 0.75 \mathrm{~cm}^{2}$ area, ensuring that cement coating identified in thin section was not sampled. Approximately $8 \mathrm{mg}$ of carbonate was then collected for analysis from an even thickness of the interior buff-colored shell horizon of two different gastropod specimens for samples DB2-shell and DB3-shell. The same approach was used to collect the shell material from a third specimen, sample DB4-3 reported in Huntington et al. (2010). DB4-shell-2 was collected from the same location on the specimen where DB4-3 was sampled by repeating this process to remove a deeper layer of shell material.

Cement samples were obtained by removing large euhedral crystals from gastropod chamber walls using tweezers or a slow microdrill, necessarily integrating multiple CL cement zones in order to acquire enough material for precise clumped isotope analysis. Sample DB4cement was obtained near the location of DB4-1 sampled by Huntington et al. (2010) using a microdrill and integrates material from CL zones 1-4. DB2-cement, DB3-cement, and DB5-cement were plucked from the samples using tweezers, primarily integrating CL zones 5 and 6 . 

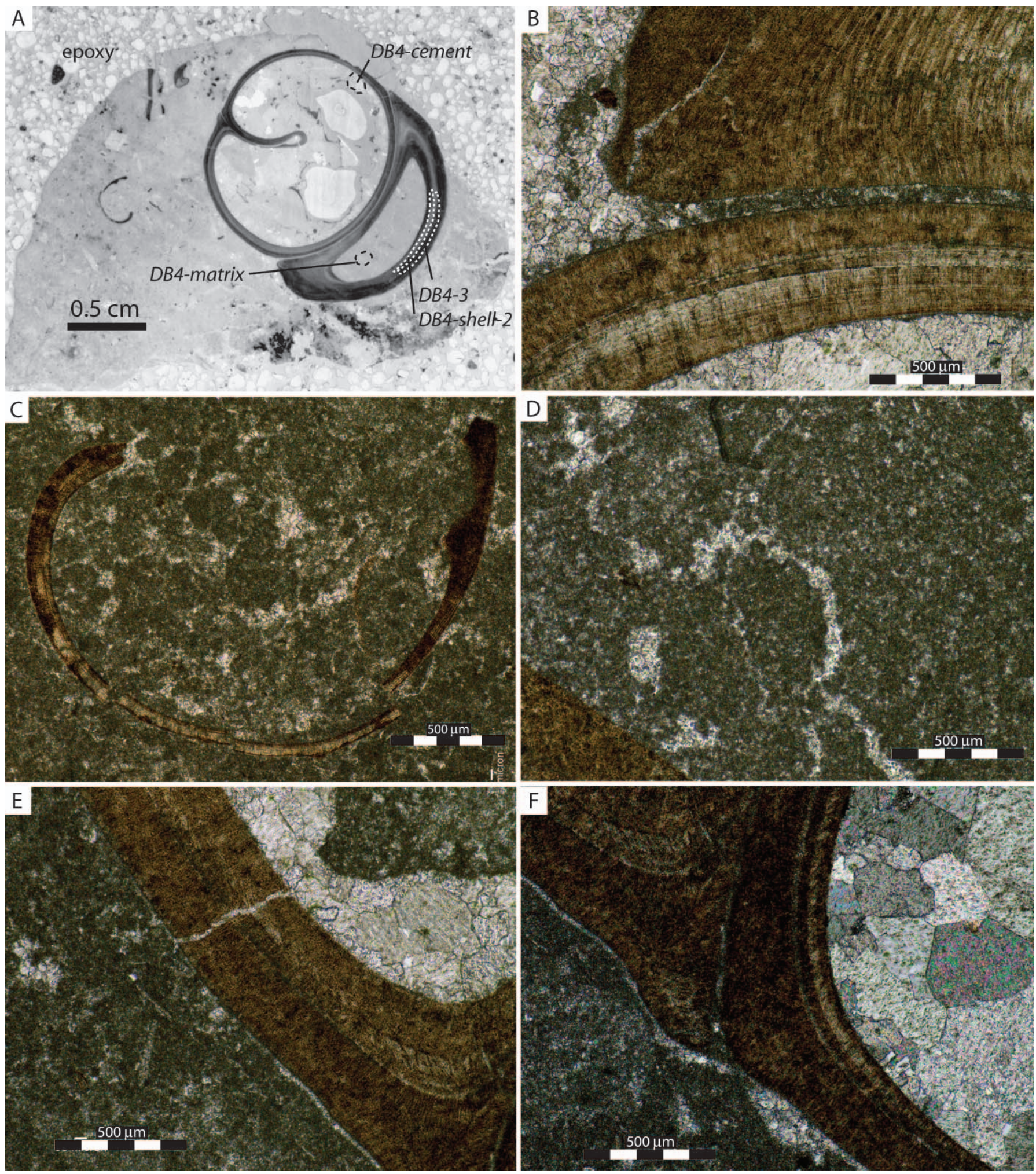

FIG. 2.-Photomicrograph of a transverse cross section through a gastropod shell (sample DB4) and images of the matrix that typify the specimens analyzed in this study as described in text. A) Photomicrograph of sample DB4, containing viviparid gastropod shell with infilling calcite spar and microspar in a sparsely fossiliferous peloidal limestone matrix. Dashed lines indicate locations from which samples DB4-3 of Huntington et al. (2010), DB4-shell2, DB4-matrix, and DB4-cement were collected. B) Photomicrograph of typical gastropod shell exhibiting parallel growth bands and cross-lamellar microstructure. C) Photomicrograph of small gastropod shell embedded in matrix. D) Photomicrograph of the sampled region labeled "DB4-matrix" in panel of Part A. E) Photomicrograph of cements filling shell microcracks. F) Photomicrograph of gastropod shell and infilling cement in cross-polarized light. 

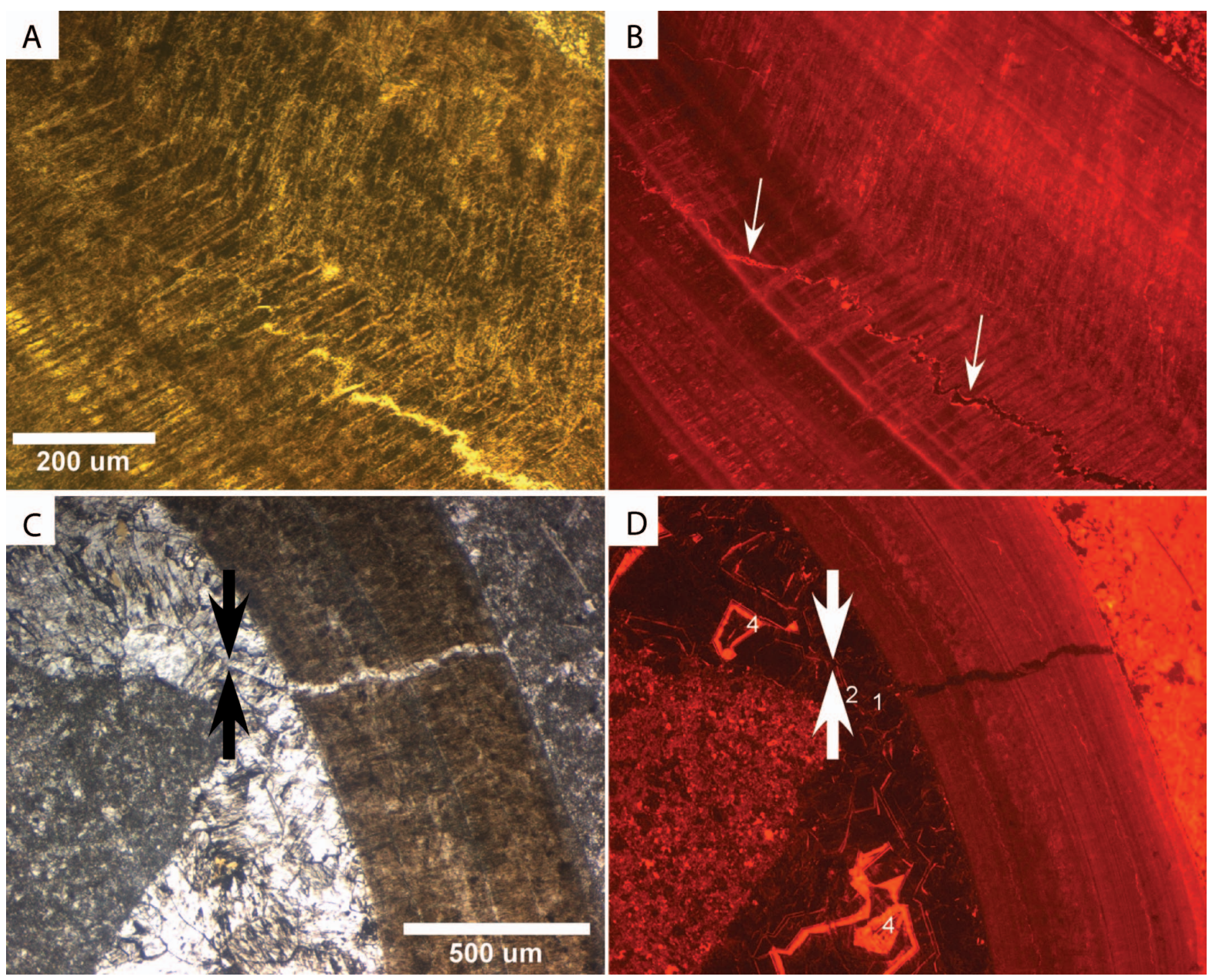

FIG. 3.-Paired plane light (left) and cathodoluminescent (CL, right) photomicrographs of gastropod shells. Scale bars in plane-light image apply to CL images. Both sets of images illustrate the dull reddish-orange luminescence of the shell. A, B) Cross-lamellar microstructure of the entire shell is partially preserved. Microcrack cutting the shell is healed with a bright orange luminescent calcite and an overlying nonluminescent calcite (white arrows). C, D) Crack through shell wall also extends into the initial cements in the body cavity of the gastropod and terminates at the paired arrows. Crack fill is nonluminescent, and it cuts cement zones 1 (nonluminescent) and 2 (thin bright orange band) but not out to zone 4. Crack and cement fill are thus coeval with CL zone 3. By analogy, the CL zones in the microcracks of image in Parts A and B are probably zone 4 (bright orange) under zone 5 (nonluminescent). This figure is in color in the on-line version.

A microdrill was used to mill matrix material from fresh surfaces corresponding to the locations shown in Figure 2A. Microdrilling permitted skeletal fragments and irregular voids filled with spar containing multiple CL zones to be avoided, but microspar and early pore-filling cements were undoubtedly included along with the micrite and peloids. DB4-matrix was sampled from matrix material that infiltrated the gastropod shell cavity as loose, soft sediment, and then was lithified within the shell. DB4-2 from Huntington et al. (2010) was sampled from matrix material in the same shell cavity, well away from any large shell fragments.

FTIR spectra can be used to distinguish calcite from aragonite in carbonate samples (especially in the small $8 \mathrm{mg}$ samples such as those collected herein) because minerals exhibit characteristic adsorption bands that are diagnostic for precise mineral identification (e.g., Lazerevs 1972; Farmer 1974; Griffiths and de Haseths 1986; Anderson et al. 2005). Reflectance spectra used for mineral identification (e.g., Farmer 1974) were obtained for shell, matrix, and cement powders using a Nicolet Magna 860 FTIR spectrometer with a SensIR Durascope diamond plate attenuated total reflection (ATR) attachment and $\mathrm{KBr}$ beam splitter at the California Institute of Technology (Caltech). The cross-lamellar microstructure of the sampled gastropod shell material indicates that the shells were originally aragonite. Comparison of FTIR spectra for the samples and standards from Caltech's internally generated mineral database (G.R. Rossman, unpublished data) in the $750-1700 \mathrm{~cm}^{-1}$ region confirms that the shells, matrix, and cements are all pure calcite. Thus calcite replaced primary shell aragonite as a result of post-mortem processes.

\section{ISOTOPIC ANALYSIS AND RESULTS}

$\mathrm{CO}_{2}$ was produced by anhydrous phosphoric acid digestion of $\sim 8 \mathrm{mg}$ of carbonate powder from each sample at $25^{\circ} \mathrm{C}$ for $12-24$ hours using a 


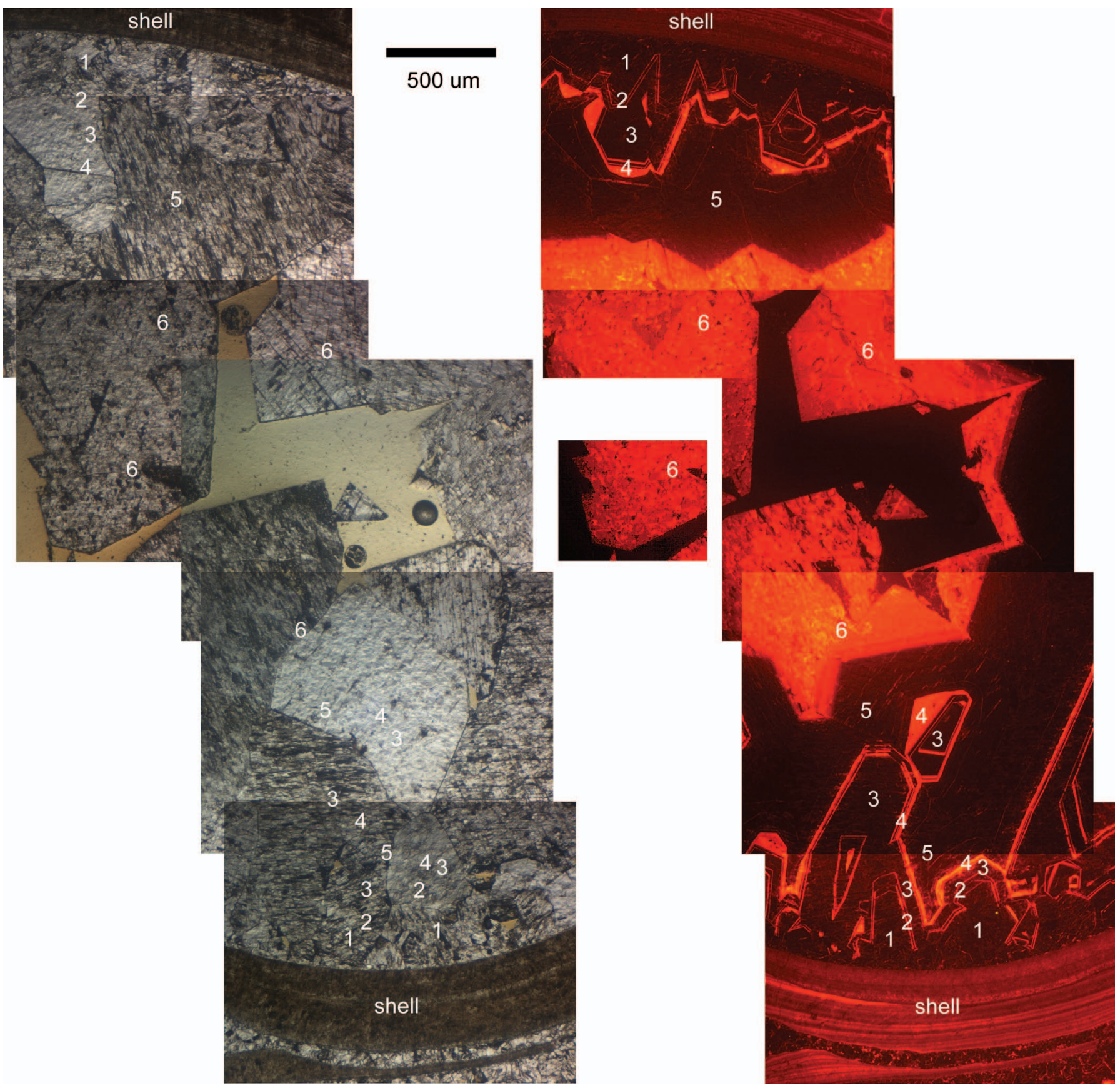

FIG. 4.-Paired plane-light (left) and cathodoluminescent (right) photomosaics of the calcite spar partially infilling the gastropod body cavity in sample DB-4. Crystal sizes increase from very fine along the shell wall to coarse-crystalline in the pore center. Six luminescent zones $(1=$ oldest, $6=$ youngest $)$ are present that crosscut individual crystals.

McCrea-type reaction vessel (McCrea 1950; Swart et al. 1991). Product $\mathrm{CO}_{2}$ was isolated and purified by conventional cryogenic procedures using the glass vacuum apparatus described by Ghosh et al. (2006a). Sample $\mathrm{CO}_{2}$ was entrained in $\mathrm{He}$ carrier gas flowing at a rate of $3 \mathrm{ml} / \mathrm{min}$ and passed through an Agilent Tech $6890 \mathrm{~N}$ gas chromatograph (GC) column (Supel-Q-PLOT column with $530 \mu \mathrm{m}$ internal diameter, $30 \mathrm{~m}$ long) held at $-10^{\circ} \mathrm{C}$, and collected for 40 minutes in a liquid $\mathrm{N}_{2}$ trap. After evacuation of the $\mathrm{He}$ carrier gas, conventional cryogenic procedures were repeated twice to purify the sample before condensation into an evacuated glass vessel for transfer to the mass spectrometer.
Isotopic analysis of $\mathrm{CO}_{2}$ was performed at Caltech on a Finnigan MAT 253 mass spectrometer configured to measure masses 44-49 (Eiler and Schauble 2004). Values for $\delta^{13} \mathrm{C}$ and $\delta^{18} \mathrm{O}$ of calcite reported vs. VPDB were calculated using the program Isodat 2.0 and standardized by comparison with $\mathrm{CO}_{2}$ evolved from phosphoric acid digestion of the NBS-19 carbonate standard distributed by the International Atomic Energy Agency. The $\Delta_{47}$ values were calculated based on raw measurements of ${ }^{45} \mathrm{R},{ }^{46} \mathrm{R}$, and ${ }^{47} \mathrm{R}$, where ${ }^{\mathrm{i}} \mathrm{R}$ is the abundance of mass $i$ relative to the abundance of mass 44 (Wang et al. 2004; Affek and Eiler 2006; Huntington et al. 2009). Results for 3 of 11 attempted analyses were 

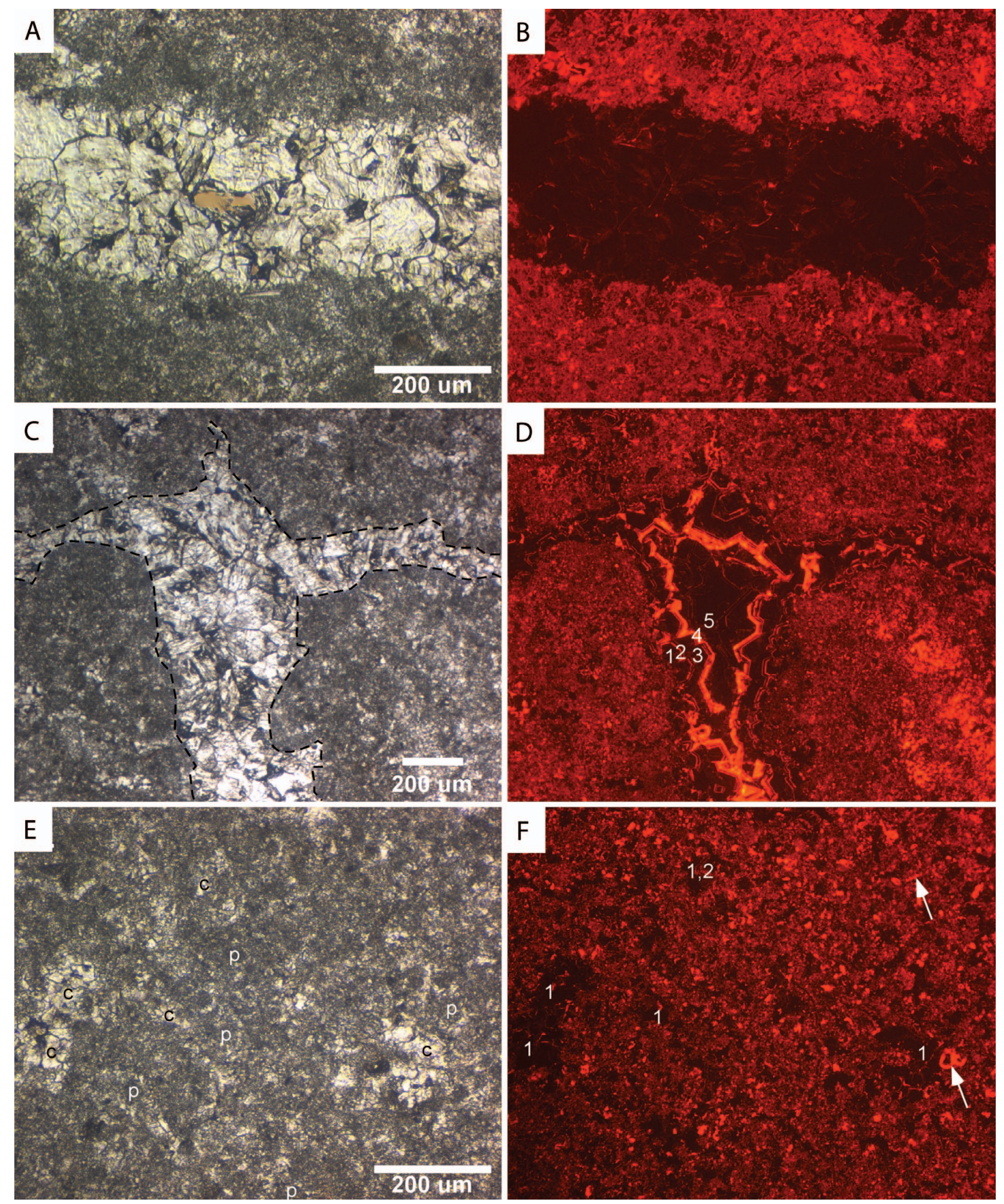

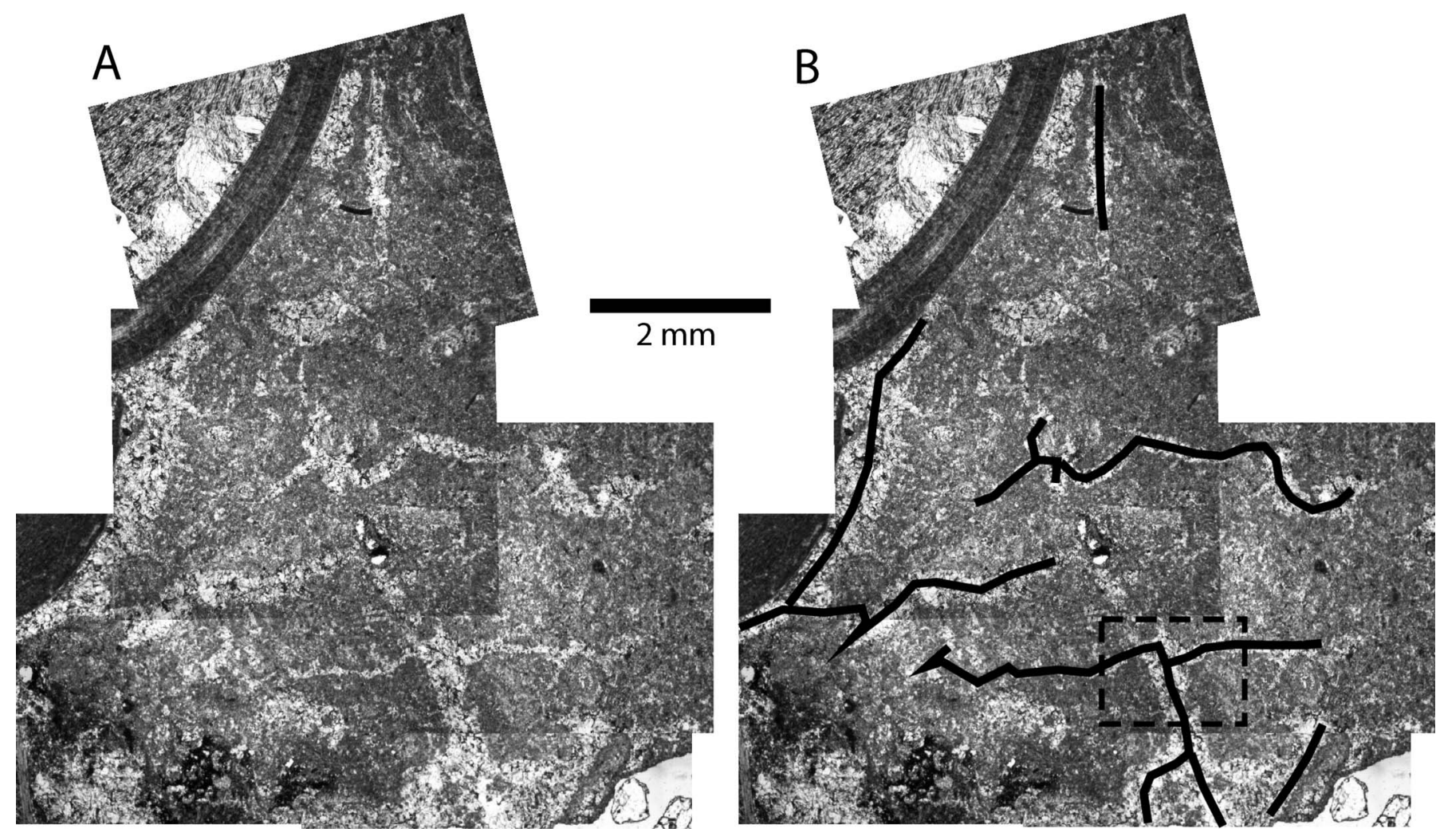

FIG. 6.-A) Photomosaic of the irregular voids that define cracks within the matrix and B) interpretation of how those cracks are connected. There is very little displacement along cracks, but the cracks are neither linear nor continuous. Box (dashed lines) marks the position of image shown in Figure 5C and D.

rejected on the basis of high mass-48 signals, which are used to screen for the presence of hydrocarbons, chlorocarbons, or sulfur-bearing contaminants that may compromise temperature estimates (Eiler and Schauble 2004; Guo and Eiler 2007; Huntington et al. 2009). Samples with mass-48 values that differ more than $2 \%$ from the mass- 48 value of clean heated $\mathrm{CO}_{2}$ with the same bulk isotopic composition as the sample were rejected (see Huntington et al. 2009 for details on the comparison of mass-48 values for samples and heated $\left.\mathrm{CO}_{2}\right)$. Stable-isotope results $\left(\delta^{13} \mathrm{C}, \delta^{18} \mathrm{O}\right.$, and $\Delta_{47}$ ) for the remaining 8 samples, and the three sets of analyses from Huntington et al. (2010), are reported in Table 1.

Values of $\Delta_{47}$ range from 0.438 to $0.670 \%$ (average 1 standard error uncertainties of $0.008 \%)$, corresponding to temperature estimates of 14 $123^{\circ} \mathrm{C}$. Temperatures were calculated using the theoretical calibration of Guo et al. (2009) for calcite, since the calibration data of Gosh et al. (2006a) extend only from 0 to $50^{\circ} \mathrm{C}$ (Table 1). Uncertainties in temperature estimates represent the 1 standard error analytical uncertainty in $\Delta_{47}$ propagated through the Guo et al. (2009) calibration, and range from \pm 3 to $6^{\circ} \mathrm{C}$. The reported error in $\Delta_{47}$ for sample DB4-3 $(0.005 \%)$ is based on replicate analyses of $\mathrm{CO}_{2}$ from two separate acid digestions (Huntington et al. 2010), and thus also accounts for external error. For comparison, using the calibration of Gosh et al. (2006a) yields temperature estimates in the 0 to $50^{\circ} \mathrm{C}$ range within 2 standard error of the values calculated using the Guo et al. (2009) equation. Using an unpublished calibration equation based on the Ghosh et al. (2006a) data and new inorganic-carbonate data generated at Caltech (M. Bonifacie, personal communication 2010) yields temperatures that overlap the values reported in Table 1 within 1 standard error. Values of $\Delta_{47}$ for two aliquots of calcified shell from the same sample agree to within 1 standard error (DB4-shell-2 and sample DB4-3 of Huntington et al. (2010)), and indicate an average temperature of $95^{\circ} \mathrm{C}$. The $\delta^{13} \mathrm{C}$ of calcite values for the shell samples range from -9.6 to $-9.1 \%$ (PDB), while the matrix and cements are less negative $(-6.6$ to $-5.5 \%)$. Analytical uncertainty in $\delta^{13} \mathrm{C}$ is less than $\pm 0.1 \%$ ( 1 standard error).

The $\delta^{18} \mathrm{O}$ of calcite values for 10 of the Long Point samples in Table 1 are tightly clustered around an average of $-15 \pm 1 \%$ (range -13.2 to $-15.3 \%$ VPDB), with analytical precision on each measurement better than $\pm 0.1 \%$. The remaining sample (DB2-cement) is more than $2 \%$ more negative than that average. In contrast, the $\delta^{18} \mathrm{O}$ values of coexisting fluids calculated from the $\Delta_{47}$ temperature estimates, measured calcite $\delta^{18} \mathrm{O}$, and the calcite-water oxygen isotope fractionation relation of Kim and O'Neil (1997) vary by $18 \%$ (Table 1). The $\delta^{18} \mathrm{O}$ of the diagenetic fluids associated with cements and matrix range from -6 to $-14 \%$ (VSMOW), whereas the range is -1 to $+4 \%$ o for the diagenetic fluids associated with the shell samples. Uncertainties in the calculated $\delta^{18} \mathrm{O}$ of water range from 0.6 to $2 \%$ (calculated by propagating the 1 standard error uncertainties in temperature and $\delta^{18} \mathrm{O}$ of calcite through

FIG. 5.-Paired plane-light (left) and cathodoluminescent (CL, right) photomicrographs of matrix components. Scale bars in plane light image apply to CL images. A, B) Small bioclast mold filled with fine-crystalline calcite cement that is non-luminescent, and interpreted to be cement zone 1 of Figure 4 . C, D) Calcite cements filling the irregular voids (outlined by dashed line) cutting through the sample are composed of luminescent zones 1 to 5 . See Figure 6 for location of the image with respect to the void network. E, F) Matrix of micrite, peloids (p), and silt-size skeletal debris (white arrows) that may be bright orange, dull red, or nonluminescent. Cements (c) are dominantly nonluminescent zone 1 calcites, although minor amounts of luminescent zones 2 cement can be present. This figure is in color in the on-line version. 
TABLE 1.-Clumped-isotope thermometry and stable isotopic results.

\begin{tabular}{|c|c|c|c|c|c|c|}
\hline sample & $\begin{array}{c}\delta^{13} \mathrm{C}_{\mathrm{VPDB}} \\
(\%)^{\mathrm{a}}\end{array}$ & $\begin{array}{c}\delta^{18} \mathrm{O}_{\mathrm{VPDB}} \\
(\%)^{\mathrm{a}}\end{array}$ & $\begin{array}{l}\Delta_{47} \\
(\% 0)\end{array}$ & $\begin{array}{c}\text { 1SE } \Delta_{47} \\
(\% 0)\end{array}$ & $\begin{array}{l}\mathrm{T}\left(\Delta_{47}\right) \\
\left({ }^{\circ} \mathrm{C}\right)^{\mathrm{b}}\end{array}$ & $\begin{array}{c}\delta^{18} \mathrm{O}_{\text {VSMOW }} \\
(\%)^{\mathrm{d}}\end{array}$ \\
\hline \multicolumn{7}{|c|}{ Calcified Shell Samples: } \\
\hline $\begin{array}{l}\text { DB2-shell } \\
\text { DB3-shell } \\
\text { DB4-3' } \\
\text { DB4-shell-2 }\end{array}$ & $\begin{array}{l}-9.6 \\
-9.1 \\
-9.2 \\
-9.2\end{array}$ & $\begin{array}{l}-13.6 \\
-13.2 \\
-14.3 \\
-14.3\end{array}$ & $\begin{array}{l}0.466 \\
0.438 \\
0.482 \\
0.478\end{array}$ & $\begin{array}{l}0.008 \\
0.008 \\
0.005 \\
0.008\end{array}$ & $\begin{array}{r}104 \pm 5 \\
123 \pm 6 \\
94 \pm 3 \\
96 \pm 5\end{array}$ & $\begin{array}{c}1.3 \pm 0.6 \\
4.1 \pm 0.7 \\
-1 \pm 1 \\
0 \pm 2\end{array}$ \\
\hline \multicolumn{7}{|l|}{ Cement Samples: } \\
\hline \multicolumn{7}{|c|}{ Matrix Limestone Samples: } \\
\hline $\begin{array}{l}\text { DB4-matrix } \\
\text { DB4-2 }{ }^{\mathrm{c}}\end{array}$ & $\begin{array}{l}-6.6 \\
-6.6\end{array}$ & $\begin{array}{l}-14.4 \\
-14.4\end{array}$ & $\begin{array}{l}0.612 \\
0.597\end{array}$ & $\begin{array}{l}0.007 \\
0.007\end{array}$ & $\begin{array}{l}34 \pm 3 \\
39 \pm 3\end{array}$ & $\begin{array}{r}-10 \pm 1 \\
-9 \pm 1\end{array}$ \\
\hline
\end{tabular}

${ }^{\mathrm{a}} 1$ standard error (1SE) analytical uncertainties in measured $\delta^{18} \mathrm{O}$ and $\delta^{13} \mathrm{C}$ of carbonate are less than $0.1 \%$.

b Temperature estimates $\left(\mathrm{T}\left(\Delta_{47}\right)\right)$ were calculated from measured $\Delta_{47}$ using theoretical calibration of Guo et al. (2009) for calcite. Uncertainty in temperature estimates is based on the 1SE analytical uncertainty in measured $\Delta_{47}$ propagated through the Guo et al. (2009) equation, except for sample DB4-3, which was analyzed twice, and for which the reported error reflects external error (see text for details).

${ }^{c}$ Original average $\Delta_{47}, \delta^{18} \mathrm{O}$, and $\delta^{13} \mathrm{C}$ values from Huntington et al. (2010) are reported, with revised temperature estimates calculated from $\Delta_{47}$ using equation of Guo et al. (2009) for calcite.

${ }^{\mathrm{d}}$ The estimated $\delta^{18} \mathrm{O}$ of water in equilibrium with each calcite sample was derived from the measured $\delta^{18} \mathrm{O}$ of calcite and clumped-isotope temperature estimate using

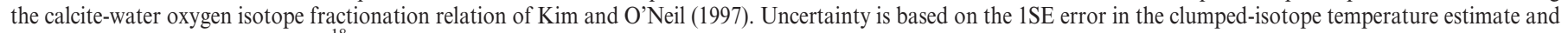
$0.1 \%$. 1 SE error in the measured $\delta^{18} \mathrm{O}$ of calcite propagated through the Kim and O’Neil (1997) equation.

the equation of Kim and O'Neil (1997)). The $\delta^{18} \mathrm{O}$ of water and temperature estimates for the earliest cements (from DB4) and both matrix samples are within the range of plausible Earth surface conditions. However, temperature estimates for the remaining samples are $49-123^{\circ} \mathrm{C}$, suggesting that they were influenced by diagenetic alteration during a postdepositional thermal perturbation.

\section{THERMAL HISTORY OF LONG POINT SAMPLES}

Stratigraphic considerations point to emplacement of the basalt, rather than depositional burial, as the source of heat for the temperatures in excess of typical Earth surface conditions. Deposition of $4 \mathrm{~km}$ of overlying sediment would be required to place the sampled limestone horizon at a temperature of $\sim 120^{\circ} \mathrm{C}$ (the warmest sample temperature estimated by clumped-isotope thermometry), assuming a mean annual surface temperature of $20^{\circ} \mathrm{C}$ through most of the pre-Miocene (Fricke and Wing 2008; Yapp 2008) and a geothermal gradient of $25^{\circ} \mathrm{C} / \mathrm{km}$. If a higher geothermal gradient characteristic of volcanic source areas on the plateau is considered $\left(40^{\circ} \mathrm{C} / \mathrm{km}\right.$, Reiter et al. 1979), $2.5 \mathrm{~km}$ of sediment would be required. At the sample locality on the Coconino Plateau, the precise maximum depth of burial of the samples is unknown, because no record remains of mid-Eocene through early Miocene sediment that may have accumulated and then been eroded above the Music Mountain Formation prior to emplacement of the late Miocene basalt. However, no sedimentologic evidence in the broader region suggests that there were ever more than a few hundred meters of Cenozoic sediment above the early Eocene limestones in the southern Plateau (Young 1999). Even allowing for $500 \mathrm{~m}$ of deposited and now eroded Eocene and younger sediments and a high geothermal gradient of $40^{\circ} \mathrm{C} / \mathrm{km}$, it is unlikely the sampled horizon would have achieved a temperature $>40^{\circ} \mathrm{C}$ due to burial heating (or greater than $30^{\circ} \mathrm{C}$ if the cooling effect of surface groundwater circulation is considered).

(U-Th)/He data for apatites from the Music Mountain Formation at Long Point and to the northwest near Frazier Wells (Flowers et al. 2008) also support the notion that depositional burial was not the source of heat for temperatures up to $\sim 120^{\circ} \mathrm{C}$ recorded by carbonate clumped-isotope thermometry. Apatite $(\mathrm{U}-\mathrm{Th}) / \mathrm{He}$ thermochronometry is sensitive to temperatures from ca. 40 to $75^{\circ} \mathrm{C}$ over geologic timescales (Wolf et al. 1996; Farley 2000), and postdepositional He loss in apatites can constrain reheating events in and above this range. Observed (U-Th)/He dates for Music Mountain Formation apatites from an arkose collected near Frazier Wells are heterogeneous (range 48 to $77 \mathrm{Ma}$ ), with some dates older than the unit's early Eocene depositional age, suggesting no significant postdepositional He loss (Flowers et al. 2008). Thermal histories simulated using the program HeFTy (Ketcham 2005) show that burial heating to peak temperatures in excess of $\sim 80^{\circ} \mathrm{C}$ would have caused complete He loss in the apatites, resulting in a narrow distribution of late Oligocene-early Miocene (U-Th)/He dates. The data do not fit this pattern, precluding a protracted period of reheating due to burial. (UTh)/He data collected by Flowers et al. (2008) for apatites from a volcanic cobble and a granitic cobble from the Music Mountain Formation at Long Point (Fig. 1) also show a wide spread of dates (51 to $153 \mathrm{Ma}$ ), which HeFTy simulations indicate is inconsistent with burial heating to peak temperatures greater than $80^{\circ} \mathrm{C}$.

In contrast, three of five detrital apatites from a coarse arkose in the same outcrop as the volcanic cobble $\sim 20 \mathrm{~m}$ below the basalt at Long Point show evidence of postdepositional He loss (Flowers et al. 2008). Anomalously young dates for these apatites are inconsistent with other thermochronologic and geochronologic constraints in the area, and although Flowers and co-workers suggest the He loss may be related to a thermal disturbance associated with the basalt flow, it is difficult to explain how only three of ten apatites from the same outcrop exhibited this behavior when their proximity suggests a shared thermal history. We could speculate that high-U rims on the detrital apatites rather than $\mathrm{He}$ loss contributed to the anomalous dates (R.M. Flowers and K.A. Farley, personal communication 2011). But regardless of the reason for the three young dates, the other 13 apatites from Long Point and 6 apatites from Frazier Wells indicate no significant postdepositional He loss and could not have been heated to peak burial temperatures over $80^{\circ} \mathrm{C}$. Thus burial reheating cannot account for calcite clumped-isotope temperatures up to $\sim 120^{\circ} \mathrm{C}$ in the Music Mountain Formation.

Since burial is not a viable heat source, we hypothesize that the overlying basalt flow could have raised the limestone samples to the 


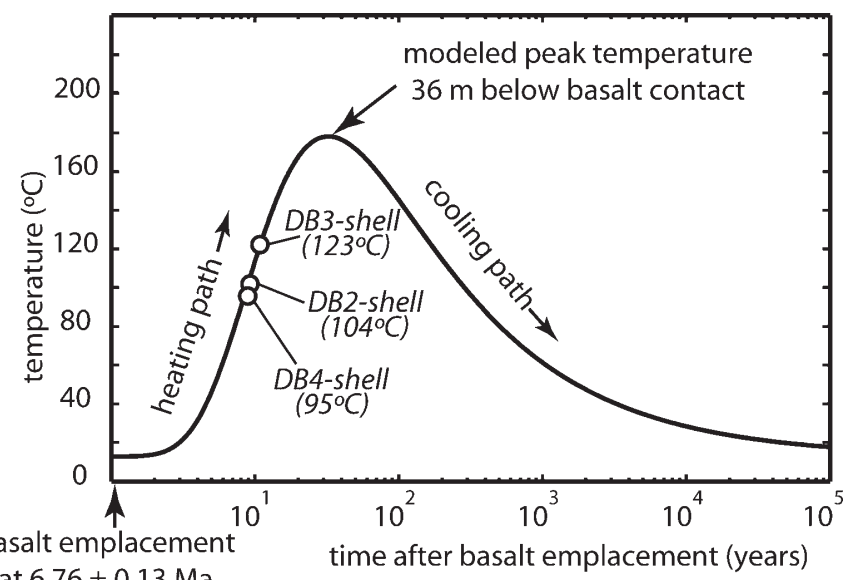

at $6.76 \pm 0.13 \mathrm{Ma}$

FIG. 7.- Modeled temperature-time path following basalt emplacement for sample located $36 \mathrm{~m}$ below the basalt-country rock contact, as described in text. The white circles indicate points at which calcified-shell temperatures are reached on the heating limb of the modeled temperature-time path.

elevated temperatures indicated by the clumped-isotope data. We estimate the amount of heating likely experienced by the carbonate samples resulting from extrusion of overlying basalt at Long Point using a simple 1D conductive thermal model (Carslaw and Jaeger 1986; Philpotts 1990). The temperature $T$ at depth $x$ in the country rock below the center of the basalt at time $t$ after flow emplacement is given by

$$
T(x, t)=T_{0}+\frac{\left(T_{S}-T_{0}\right)}{2}\left[\operatorname{erf}\left(\frac{a-x}{2 \sqrt{k t}}\right)+\operatorname{erf}\left(\frac{a+x}{2 \sqrt{k t}}\right)\right]
$$

where $T_{s}$ is the solidification temperature of the lava, $T_{0}$ is the initial country rock temperature and air temperature, $2 a$ is the flow thickness, and $k$ is the thermal diffusivity of the basalt and country rock (Carslaw and Jaeger 1986). We assume the commonly used value of $1 \times 10^{-6} \mathrm{~m}^{2} / \mathrm{s}$ for $k$, and that the lava was emplaced near its crystallization temperature, estimated to be $1100^{\circ} \mathrm{C}$. In order to obtain a conservative estimate of the temperatures reached by the samples, we assume a flow thickness of $20 \mathrm{~m}$, the minimum thickness of basalt above the sampled outcrop, and that $T_{0}$ is $12^{\circ} \mathrm{C}$, the present-day mean annual air temperature at nearby Seligman, Arizona, rather than warmer estimated early Eocene surface temperatures (Fricke and Wing 2008).

The temperature evolution of a lava flow and underlying country rock depend on a number of factors that are not captured by this simple model. Radiative heat loss from the lava flow to the atmosphere is affected by air temperature, wind, and precipitation (e.g., Patrick et al. 2004) but diminishes rapidly with decreasing temperature, typically in less time (minutes to hours) than it takes to emplace the flow. However, convective heat loss to the atmosphere continues throughout cooling (Neri 1998) and would lead to more rapid cooling of the lava. Vertical circulation of fluids within the permeable country rock would tend to homogenize and/or buffer temperatures in the top $100 \mathrm{~m}$ or more. Although cooling estimated by conductive and convective models of heat transfer within a lava flow do not differ significantly (Worster et al. 1993), latent heat of crystallization (e.g., Shaw et al. 1977), changes in thermal conductivity with temperature (Murase and McBirney 1973), and vesiculation (Keszthelyi 1994) have time-varying effects on cooling within the flow. Of these, we consider only the effect of latent heat of crystallization on temperatures in the country rock. We incorporate the amount of heat equivalent to the heat liberated by crystallization by adjusting the initial temperature of the lava upward, substituting $\left(T_{0}+L\right.$ $/ C_{p}$ ) for $T_{0}$ in Equation 1 (Philpotts 1990), where $L$ is the latent heat of crystallization and $C_{p}$ is the heat capacity $\left(4 \times 10^{5} \mathrm{~J} / \mathrm{Kg}\right.$ and $840 \mathrm{~J} / \mathrm{Kg} \cdot \mathrm{K}$, respectively). Although this analytical approximation predicts basalt temperatures that are too high, it provides a close estimate of the effect of latent heat of crystallization on the rate of cooling in the country rock.

At the position of the limestone samples $36 \mathrm{~m}$ below the basalt contact, the model predicts that a maximum temperature of $\sim 180^{\circ} \mathrm{C}$ is attained within a few decades of basalt emplacement, and subsequent cooling below $20^{\circ} \mathrm{C}$ takes on the order of $10^{5}$ years (Fig. 7). Even with a very low estimate for the basalt temperature of $600^{\circ} \mathrm{C}$, the model predicts maximum temperatures of at least $120^{\circ} \mathrm{C}$ at the sampled horizon within decades of flow emplacement. We note that heating up to the maximum clumped-isotope temperatures is plausible in light of apatite (U-Th)/He data, since HeFTy simulations indicate apatites in the Music Mountain Formation could have experienced peak temperatures up to $180^{\circ} \mathrm{C}$ before exhibiting obvious He loss because the heat pulse from the basalt flow is short lived. Given the proximity of the limestone samples to the basalt contact, it is unlikely that incorporating additional complexity in the thermal model would substantially change the prediction of rapid heating of the samples to temperatures up to or in excess of those recorded by clumped-isotope thermometry, supporting the idea that basalt emplacement is the simplest viable mechanism for postdepositional heating of the samples.

\section{TEMPERATURE AND TIMING OF DIAGENETIC EVENTS}

On the basis of textural evidence and crosscutting relationships, we infer that the diagenetic history of these relatively simple rocks can be divided into three temporal groupings: (1) precipitation of the earliest cements (CL zones 1 and 2) in the matrix and as the initial cements within the gastropod shell, relatively soon after deposition as suggested by the presence of an intraclast of matrix within the gastropod; (2) compaction of the sediments, which created cracks within the matrix and within the larger gastropods, and healing of these cracks and overgrowth of porefilling cement in the interior of the gastropods (CL zones 3, 4, and 5); and (3) precipitation of a final phase of cement (CL zone 6) within the centers of the gastropod interiors. Based on textural evidence, the timing of shell alteration from aragonite to calcite is unknown within this three-step sequence, although the similarity of the $\delta^{18} \mathrm{O}$ values of the shells, micrite, and earliest-formed cements (DB4-cement, DB4-1) would argue for shell alteration early in that diagenetic history. In fact, in the absence of clumped-isotope thermometry data, the similarity of $\delta^{18} \mathrm{O}$ values for all of the carbonate samples might suggest that all three diagenetic steps were closely spaced in time, and facilitated by meteoric groundwaters at nearsurface temperatures. As discussed in the following paragraphs, clumpedisotope data indicating a large range of calcite formation temperatures $\left(14\right.$ to $\left.123^{\circ} \mathrm{C}\right)$ clearly demonstrate that this is not the case.

\section{Diagenesis of the Gastropod Shells}

The primary aragonitic gastropod shells would have been metastable at Earth's surface and readily converted to calcite in meteoric waters or during thermal perturbation. Without the $\Delta_{47}$ data, a logical conclusion would be the aragonite-to-calcite transformation was an early event coeval with precipitation of the earliest cements (DB4-cement) and lithification of the matrix, given that all three have the same calcite $\delta^{18} \mathrm{O}$ values. However, the range of temperatures recorded by the calcified shells and thermal model allow us to constrain the timing of aragonite-tocalcite transition to the narrow window between $\sim 10$ and several hundred years following the basalt emplacement in late Miocene time (Fig. 7).

It is unlikely that these sediments remained dry during shallow burial, since they are overlain by alluvial deposits and the water table was often above them. We speculate that with fluid present in the rock throughout the thermal perturbation, calcite replacement would have occurred the 
first time some temperature threshold for aragonite stability was exceeded during heating. Given the consistency of temperature estimates for the shell samples, agreement between temperatures recorded by inner and outer layers of the same shell, and the thermal model shown in Figure 7, this would require completion of the aragonite-calcite transformation in a few years or less. Laboratory experiments indicate that low-temperature $\left(<100^{\circ} \mathrm{C}\right)$ aqueous calcite-aragonite transformation can occur rapidly (e.g., Taft 1967), suggesting that the kinetics of transformation may have been rapid enough to permit such a transition. In this case, the clumpedisotope signal would correspond to the first time the samples reached 95$123^{\circ} \mathrm{C}$, within a decade of basalt emplacement. The variation in replacement temperature $\left(27^{\circ} \mathrm{C}\right)$ requires that the alteration of different shells occurred just a few years apart, possibly due to slight variations in the permeability of surrounding sediment and/or fluid chemistry. Calcification on the heating path would imply that the calcified samples resisted resetting during subsequent heating to peak temperatures of $\sim 180^{\circ} \mathrm{C}$ (Fig. 7).

Preservation of the cross-lamellar microstructure in the shells (Figs. 2, 3 ) indicates that the aragonite-to-calcite transformation occurred across thin films (Wardlaw et al. 1978; Pingitore 1982; Machel et al. 1991; Maliva and Dickson 1992). Thin films are isolated microenvironments that typically are partially to completely rock buffered with respect to stable isotopes and trace elements, but diffusive transport of reactants and products between the film and the "bulk pore waters" does occur.

Changes in $\delta^{18} \mathrm{O}$ of the fluid and shells that accompany changes in temperature (Table 1) permit us to model the isotopic evolution of the thin-film fluid-rock system recorded by our shell samples (Fig. 8). Following the method of Banner and Hansen (1990), we modeled heating from 0 to $150^{\circ} \mathrm{C}$, an initial $\delta^{18} \mathrm{O}$ of carbonate equal to the average of the earliest-formed cements $\left(-14.6 \%\right.$ VPDB), and initial $\delta^{18} \mathrm{O}$ of water values spanning the range of modern surface and shallow ground waters near Long Point ( -2.5 to $-15 \%$, Guay et al. 2004). This range of fluid $\delta^{18} \mathrm{O}$ also covers the range of fluid $\delta^{18} \mathrm{O}$ calculated for all cements in our samples. We assume the value of $-14.6 \%$ for the precursor aragonite to be a reasonable estimate of carbonate in equilibrium with Eocene meteoric waters.

Open-system solutions, in which repeated addition of fluid with constant isotopic composition buffers the system, predict up to $5 \%$ variations in $\delta^{18} \mathrm{O}$ of carbonate over the range of temperatures spanned by the shell calcite samples (Fig. 8A, B). This pattern does not resemble our data. In contrast, closed-system isotopic evolution during heating fit the data well, regardless of initial water composition, as long as the water-rock ratio does not exceed $\sim 0.01$ weight $\%$ (Fig. 8C, D). This result not only supports the interpretation of aragonite-calcite alteration in a rock-buffered system, but also explains the range of -1 to $+4 \%$ in fluid $\delta^{18} \mathrm{O}$ composition observed for the rock-dominated alterations. At the very low water-rock ratios indicated, the agreement of the dashed lines in Figure 8C and D indicate that a wide range of oxygen isotopic compositions are possible for the parent fluid.

\section{Cementation History}

The large range of calcite cement growth temperatures $\left(14-65^{\circ} \mathrm{C}\right.$; Table 1) and CL patterns confirm a prolonged period of cement precipitation. The earliest-formed cements, which constitute samples DB4-cement and DB4-1, formed at $14-19^{\circ} \mathrm{C}$ early in the rock's history from early Eocene shallow meteoric groundwaters with a $\delta^{18} \mathrm{O}$ value of -13 to $-14 \%$. Clumped-isotope temperatures of $14-19^{\circ} \mathrm{C}$ are compatible with early Eocene mean annual temperature estimates of $14-23^{\circ} \mathrm{C}$ from the western United States (Fricke and Wing 2008; Yapp 2008). In contrast, cement samples that integrate material other than CL cement zones 1-4 record temperatures well in excess of surface conditions, indicating that they contain some component of calcite that was precipitated in association with the thermal perturbation millions of years later.

The DB4-cement temperature and CL patterns constrain the timing of crack development in the gastropod shells. The crack (Fig. 3C, D) cuts into the initial fine crystalline cements that border the inside of the shell wall, cutting through CL cement zone 2, but not CL zone 4. Thus the nonluminescent and luminescent cements in the cracks are CL cement zones 3 and 4, respectively. DB4-cement sampled CL zones 1-4 and returned a clumped-isotope temperature of $14^{\circ} \mathrm{C}$, suggesting that the crack fills in the shell are also low-temperature precipitates that formed from shallow groundwaters. Thus the shell cracks are relatively early compaction phenomena, present long before the shell material recrystallized. Since cement from CL zones 1-4 was present prior to recrystallization of the shells and exhibits no textural evidence of alteration (Fig. 3), the clumped isotope signal of DB4-cement must have resisted resetting in the presence of fluid at temperatures of at least $120^{\circ} \mathrm{C}$.

The cement samples recording temperatures of $49-65^{\circ} \mathrm{C}$ primarily integrate CL cement zones 5 and 6 , though they also may contain material from zones $1-4$. As a consequence, it is not possible to determine whether (1) all the cement in the samples formed at temperatures of 49 $65^{\circ} \mathrm{C}$ early in the thermal pulse from fluids with $\delta^{18} \mathrm{O}$ values of -6 to $-8 \%$ (Table 1), or (2) those samples contain a mixture of $95-123^{\circ} \mathrm{C}$ cements formed concurrently with shell alteration and lower-temperature phases formed at the onset of heating and/or in early Eocene groundwater. Nevertheless, some portion of these cement samples must have formed at temperatures in excess of Earth surface conditions. Such an interpretation is unlikely to have been reached based on textural and $\delta^{18} \mathrm{O}$ data alone. Even though the composite nature of the sample prohibits determination of the specific formation temperature and fluid $\delta^{18} \mathrm{O}$ values, only the addition of the $\Delta_{47}$ data makes it possible to infer that the late phases of the cement history (CL cement zones 5 and/or 6) precipitated in association with a thermal pulse.

\section{Interpretation of Matrix Calcite Temperatures}

Because of the polygenetic nature of the matrix, we hesitate to interpret the $34^{\circ}$ to $39^{\circ} \mathrm{C}$ clumped-isotope temperatures of the matrix uniquely. The presence of the intraclast of matrix within the gastropod indicates that initial cementation of at least some lime mud happened quickly. Thus the $\Delta_{47}$ value of both the micrite and very fine-crystalline pore-filling nonluminescent cement (CL zone 1) in the matrix should record early Eocene surface temperatures like DB4-cement. However, the CL zonation of cements in the irregular matrix voids (e.g., Fig. 5D) indicates that these voids healed over a longer period of time, and likely record higher calcite formation temperatures associated with the thermal perturbation. We cannot rule out that some fraction of the brightly luminescent phases within the matrix might also have a similar origin. Thus, matrix samples could represent a mixture of phases formed at various early, near-surface temperatures as well as some higher-temperature phase(s). Additionally, if some of the micrite was originally aragonite, the temperature of its transformation to calcite also must contribute to the average $\Delta_{47}$ values of the matrix samples. In spite of these uncertainties, the $\Delta_{47}$-derived temperatures of $34^{\circ}$ to $39^{\circ} \mathrm{C}$ dictate that at least some component of the matrix precipitated at temperatures significantly higher than depositional conditions - a conclusion that would not be apparent based on $\delta^{18} \mathrm{O}$ data alone.

\section{CONCLUSIONS}

To our knowledge, this work represents the first report of multiple temperatures recorded by clumped-isotope thermometry of texturally distinct calcites in the same specimen. Our study of these samples bears on several issues relating to the use of $\Delta_{47}$ thermometry to (1) provide 

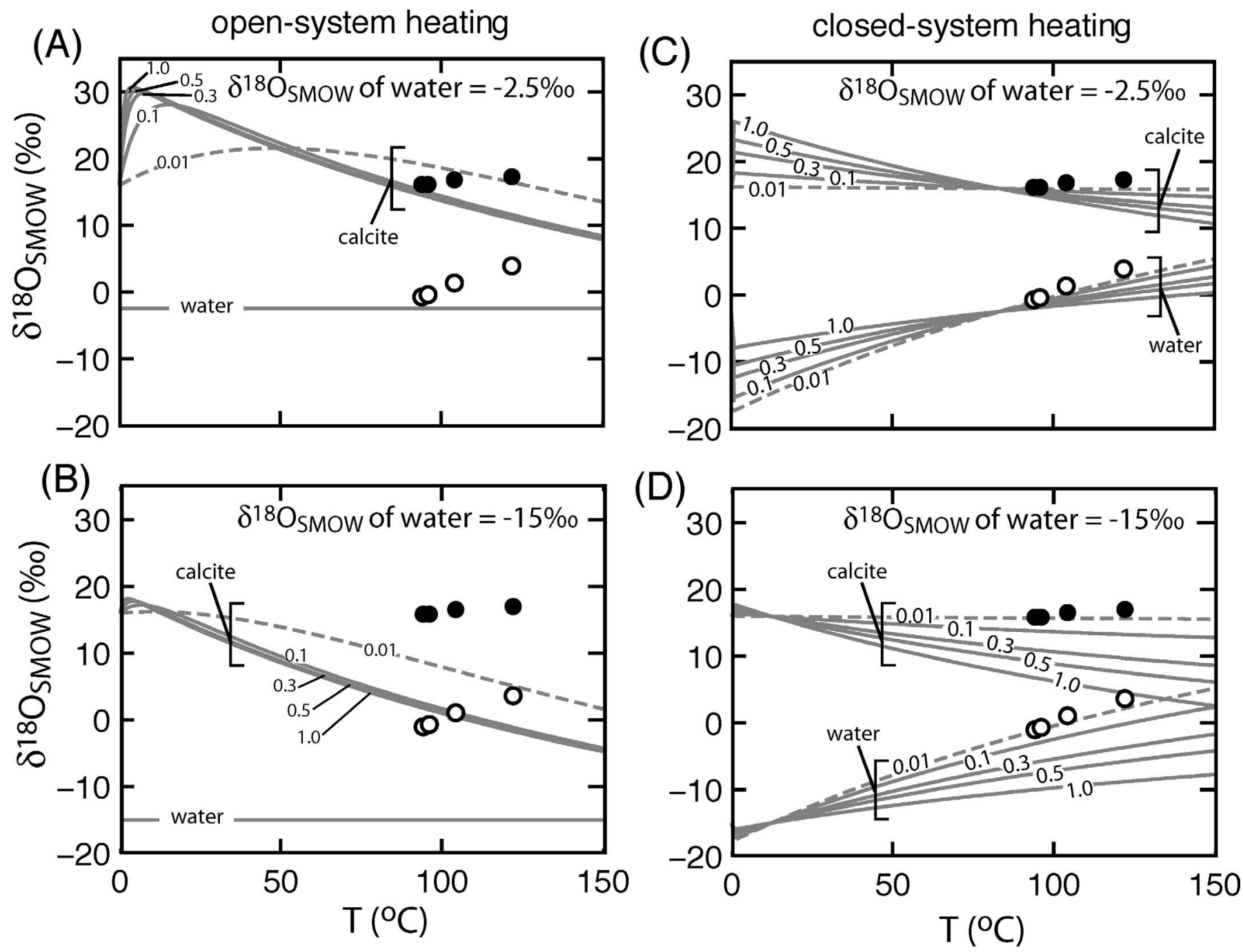

Fig. 8.-Measured and calculated isotopic values for the shell samples and coexisting fluids compared to predictions of the $\delta^{18} \mathrm{O}$ evolution for shell calcite and fluid during A) closed-system and B) open-system heating, based on the methods of Banner and Hansen (1990). Closed circles indicate measured $\delta^{18} \mathrm{O}$ of calcite values, and open circles indicate $\delta^{18} \mathrm{O}$ of waters in equilibrium with these calcites, as described in the text. The values for the initial $\delta^{18} \mathrm{O}$ of water span the range observed for modern surface and shallow ground waters in the study region ( -2.5 to $-15 \%$; Guay et al. 2004). Lines are contoured for water-to-rock ratio (weight $\%)$. Initial $\delta^{18} \mathrm{O}$ of carbonate $(-14.6 \% \mathrm{VPDB})$ is equal to the average of the earliest formed, lowest-temperature cements (Table 1). For open-system solutions, repeated addition of fluid with the same initial isotopic composition buffers the system, such that large variations in $\delta^{18} \mathrm{O}$ of carbonate occur while $\delta^{18} \mathrm{O}$ of the fluid remains constant. For closed-system solutions, $\delta^{18} \mathrm{O}$ of the fluid and carbonate evolve. For low water-to-rock ratios (W/R $\leq 0.01$ weight $\%$, or 0.06 molar), the closed system model agrees well with observed $\delta^{18} \mathrm{O}$ of the carbonate and calculated $\delta^{18} \mathrm{O}$ of the fluid in equilibrium with calcified shells at the growth temperatures indicated by clumped-isotope thermometry.

constraints on a rock's diagenetic history that would not be possible based on petrographic analysis and conventional isotope data alone and (2) access primary environmental temperatures in samples that have undergone postdepositional reheating. Importantly, our findings also demonstrate how careful petrographic characterization of samples, including CL microscopy, can maximize the value added by the application of clumped-isotope thermometry in paleotemperature investigations of both the shallow crust and Earth's surface.

Clumped-isotope thermometry can constrain directly the temperature of crystal growth for diagenetic phases of carbonate, providing new information regarding the postdepositional history of sediments. In the absence of clumped-isotope thermometry data, the logical conclusion is that the aragonite-to-calcite transformation of the shells was contemporaneous with the formation of all cements and lithification of the matrix given that all three phases have the same $\delta^{18} \mathrm{O}$ values. However, $\Delta_{47}$ results demonstrate that the aragonite-to-calcite alteration of shells occurred at temperatures in excess of $95^{\circ} \mathrm{C}$ in a highly rock-buffered microenvironment, and cementation occurred at temperatures ranging from 14 to at least $65^{\circ} \mathrm{C}$. The postdepositional heating event, prolonged history of cement growth, and high-temperature mineralogical stabilization are apparent only with clumped-isotope thermometry.

Combined with independent constraints on the nature and timing of the heating event, the clumped-isotope data permit the timing of shell alteration to be estimated in unusual detail - to within a decade of the 6.76 Ma emplacement of the lava flow. In cases for which more precise independent constraints on the temperature-time path of samples are available, e.g., based on thermochronometric data or basin modeling, $\Delta_{47}$ data have the potential to link directly the precipitation of multiple diagenetic phases and the isotopic composition of their diagenetic waters to a particular point in time. Such constraints could complement vitrinite 
reflectance data, which reflect both temperature and time. Such constraints also could provide new insight into the temperature and evolving isotopic character of diagenetic fluids in diverse basin settings, including the interaction of faults, fractures, and fluid flow, a central issue in the recovery of water, hydrocarbon, and geothermal resources and in understanding crustal deformation.

Given the large sample-size requirements of clumped-isotope analysis $(\sim 8 \mathrm{mg}$ per analysis at the time the measurements presented in this study were performed), our work suggests that careful petrographic characterization of samples including CL microscopy prior to sampling is necessary to maximize the return on clumped-isotope thermometry data. The difficulty of isolating texturally homogeneous samples of sufficient size and the limitations of interpreting $\Delta_{47}$ results for samples that integrate multiple generations of carbonate highlight the need for analytical developments to enable precise analysis of much smaller samples. Analytical improvements are underway; mass spectrometer front-end modifications have enabled $3-4 \mathrm{mg} \mathrm{CaCO}_{3}$ samples to be analyzed with no loss of precision in $\Delta_{47}$ (Zaarur et al. in press), and use of a Kiel IV carbonate device has enabled 1-2 $\mathrm{mg} \mathrm{CaCO}_{3}$ samples to be analyzed with some loss of precision (Schmid and Bernasconi 2010).

Finally, our results provide evidence that some phases can preserve a record of primary Earth-surface temperatures, even when other phases of carbonate in a rock (i.e., fossilized shells) undergo resetting due to postdepositional alteration. Whereas most carbonate phases we analyzed record elevated temperatures associated with the thermal pulse, we find that early calcite cement (DB4-cement, DB4-1) formed at $14-19^{\circ} \mathrm{C}$ from shallow meteoric groundwaters in Eocene time resisted resetting of the $\Delta_{47}$ signal via dissolution and reprecipitation and/or diffusion during heating to $95-123^{\circ} \mathrm{C}$ or more in the presence of fluids. This finding is particularly significant in light of the fact that, lacking detailed petrographic analysis, previous workers concluded that no robust paleoenvironmental information could be retrieved from this specimen (Huntington et al. 2010). Future studies combining detailed textural analysis and clumped-isotope thermometry of samples with known burial and thermal histories are needed to understand the conditions under which $\Delta_{47}$ and/or $\delta^{18} \mathrm{O}$ (and $\delta^{13} \mathrm{C}$ ) resetting of different types of primary carbonate occurs and the degree to which reset samples may record meaningful information regarding paleo-geothermal gradients.

\section{ACKNOWLEDGMENTS}

This work was supported by National Science Foundation grant EAR0610115 and the Caltech Tectonics Observatory. Acknowledgment is made to the donors of the American Chemical Society Petroleum Research Fund for support of this research (ACS-PRF grant 49709 to KWH). We thank reviewers Peter Eichhubl and Stefano Bernasconi, editor Gene Rankey, and associate editor Leslie Melim for helpful reviews. We are grateful to R.A. Young for access to his sample archive and field observations, to G.R. Rossman for assistance with Fourier transform infrared spectroscopy, to J. Harnmeijer and B.C. Schreiber for assistance with microscopy, and to R.M. Flowers, S. Bergman, and $\mathrm{O}$. Bachmann for discussions that improved the paper.

\section{REFERENCES}

Adkins, J.F., Boyle, E.A., Curry, W.B., And Lutringer, A., 2003, Stable isotopes in deep sea corals and a new mechanism for "vital effects": Geochemica et Cosmochimica Acta, v. 67, p. 1129-1143.

AfFeK, H., AND EIler, J.M., 2006, Abundance of mass $47 \mathrm{CO}_{2}$ in urban air, car exhaust, and human breath: Geochemica et Cosmochimica Acta, v. 67, p. 1129-1143.

Affek, H., Bar-Matthews, M., Ayalon, A., Matthews, A., And Eiler, J., 2008, Glacial/interglacial temperature variations in Soreq cave speleothems as recorded by "clumped isotope" thermometry: Geochimica et Cosmochimica Acta, v. 72, p. 5351-5360.

Anderson, M.S., Andringa, J.M., Carlson, R.W., Conrad, P., Hartford, W., Shafer, M., Soto, A., Tsapin, A.I., Dybwad, J.P., Wadsworth, W., and Hand, K., 2005, Fourier transform infrared spectroscopy for Mars science: Review of Scientific Instruments, v. 76, 034101 p, doi:10.1063/1.1867012.
Banner, J.L., and Hanson, G.N., 1990, Calculation of simultaneous isotopic and trace element variations during water-rock interaction with applications to carbonate diagenesis: Geochimica et Cosmochimica Acta, v. 54, p. 3123-3137.

BARKer, C.E., AND PAWlewicz, M.J., 1986, The correlation of vitrinite reflectance with maximum temperature in humic organic matter, in Buntebarth, G., and Stegena, L., eds., Paleogeothermics: Evaluation of Geothermal Conditions in the Geological Past: Springer, Berlin, Lecture Notes in Earth Sciences, v. 5, p. 79-93.

Billingsley, G.H., Felger, T.J., And Priest, S.S., 2006. Geologic Map of the Valle $30^{\prime} \times 60^{\prime}$ Quadrangle, Coconino County, Northern Arizona, Pamphlet to accompany Scientific Investigations Map 2895: U.S. Geological Survey, Open-File Report, $22 \mathrm{p}$.

Boles, J.R., EichHubl, P., Garven, G., And Chen, J., 2004, Evolution of a hydrocarbon migration pathway along basin-bounding faults: evidence from fault cement American Association of Petroleum Geologists, Bulletin, v. 88, p. 947-970.

Came, R.E., Eiler, J.M., Veizer, J., Azmy, K., Brand, U., and Weidman, C.R., 2007, Coupling of surface temperatures and atmospheric $\mathrm{CO}_{2}$ concentrations during the Palaeozoic era: Nature, v. 449, p. 198-202.

Carslaw, H.S., and Jaeger, J.C., 1986. Conduction of Heat in Solids: Oxford, U.K. Clarendon Press, $510 \mathrm{p}$.

Cerling, T.E., 1984, The stable isotopic composition of modern soil carbonate and its relationship to climate: Earth and Planetary Science Letters, v. 71, p. 229-240.

DenNIS, K.J., AND SchraG, D.P., 2010, Clumped isotope thermometry of carbonatites as an indicator of diagenetic alteration: Geochemica et Cosmochimica Acta, v. 74, p. $4110-4122$

EILER, J.M., 2007, "Clumped-isotope" geochemistry-the study of naturally-occurring multiply-substituted isotopologues: Earth and Planetary Science Letters, v. 262, p. 309-327.

Eiler, J.M., And Schauble, E., 2004, ${ }^{18} \mathrm{O}^{13} \mathrm{C}^{18} \mathrm{O}$ in Earth's atmosphere: Geochemica et Cosmochimica Acta, v. 68, p. 4767-4777.

Elston, D.P., And Young, R.A., 1991, Cretaceous-Eocene (Laramide) landscape development and Oligocene-Pliocene drainage reorganization of transition zone and Colorado Plateau, Arizona: Journal of Geophysical Reseach, Solid Earth and Planets, v. 96 , p. $12,389-12,406$

Epstein, S., Buchsbaum, R., Lowenstam, H., and Urey, H.C., 1953, Revised carbonate water isotopic temperature scale: Geological Society of America, Bulletin, v. 64, p. $1315-1326$.

FARLEY, K.A., 2000, Helium diffusion from apatite: General behavior as illustrated by Durango fluorapatite: Journal of Geophysical Research, v. 105, p. 2903-2914.

FARLEY, K.A., 2002, (U-Th)/He dating: techniques, calibrations, and applications: Reviews in Mineralogy and Geochemistry, v. 47, p. 819-843.

FARMER, V.C., 1974. The Infrared Spectra of Minerals: Mineralogical Society, London, Monograph 4, $539 \mathrm{p}$.

Flowers, R.M., Wernicke, B., and Farley, K.A., 2008, Unroofing, incision and uplift history of the southwestern Colorado Plateau from (U-Th)/He apatite thermochronometry: Geological Society of America, Bulletin, v. 120, p. 571-587.

Fricke, H.C., AND WING, S.L., 2008, Oxygen isotope and paleobotanical estimates of temperature and $\delta^{18} \mathrm{O}$-latitude gradients over North America during the early Eocene: American Journal of Science, v. 304, p. 612-635.

GaWlick, H.J., AND BoHm, F., 2000, Sequence and isotope stratigraphy of Late Triassic distal periplatform limestones from the Northern Calcareous Alps (Kalberstein Quarry, Berchtesgaden Hallstatt Zone): International Journal of Earth Sciences, v. 89, p. $108-129$.

Ghosh, P., Adrins, J., Affek, H., Balta, B., Guo, W., Schauble, E.A., Schrag, D., AND EILER, J.M., 2006a, ${ }^{13} \mathrm{C}-{ }^{18} \mathrm{O}$ bonds in carbonate minerals: a new kind of paleothermometer: Geochimica et Cosmochimica Acta, v. 70, p. 1439-1456.

Ghosh, P., Garzione, C., AND EILER, J.M., 2006b, Rapid uplift of the Altiplano revealed through ${ }^{13} \mathrm{C}-{ }^{18} \mathrm{O}$ bonds in paleosol carbonates: Science, v. 311, p. 511-515.

Gleadow, A.J.W., Duddy, I.R., Green, P.F., and Lovering, J.F., 1986, Confined fission track lengths in apatite: a diagnostic tool for thermal history analysis: Contributions to Mineralogy and Petrology, v. 94, p. 405-415.

GoldsteIN, R.H., 2001, Fluid inclusions in sedimentary and diagenetic systems: Lithos, v. 55 , p. $159-193$

Green, P.F., Crowhurst, P.V., And Duddy, I.R., 2004, Integration of AFTA and (U$\mathrm{Th} / \mathrm{He}$ thermochronology to enhance the resolution and precision of thermal history reconstruction in the Anglesea-1 well, Otway Basin, SE Australia, in Boult, P J. Johns, D.R., and Lang, S.C., eds., Eastern Australian Basins Symposium II: Petroleum Exploration Society of Australia, Special Publication, p. 117-131.

Griffiths, P.R., AND DE Haseths, J.A., 1986. Fourier Transform Infrared Spectrometry, Second Edition: New York, Wiley-Interscience, $656 \mathrm{p}$

Guay, B.E., Estoe, C.J., Bassett, R., and Long, A., 2004, Identifying sources of groundwater in the lower Colorado River valley, USA, with $\delta^{18} \mathrm{O}, \delta \mathrm{D}$, and ${ }^{3} \mathrm{H}$ implications for river water accounting: Hydrogeology Journal, v. 14, p. 146-158.

Guo, W., AND EILER, J., 2007, Temperatures of aqueous alteration and evidence for methane generation on the parent bodies of the CM chondrites: Geochimica et Cosmochimica Acta, v. 71 , p. $5565-5575$.

Guo, W., Mosenfelder, J.L., Goddard, W.A.I., and Eiler, J.M., 2009, Isotopic fractionations associated with phosphoric acid digestion of carbonate minerals: insights from first-principles theoretical modeling and clumped isotope measurements: Geochimica et Cosmochimica Acta, v. 73, p. 7203-7225.

Hartman, J.H., 1984. Systematics, biostratigraphy, and biogeography of latest Cretaceous and early Tertiary Viviparidae (Mollusca, Gastropoda) of southern Saskatchewan, western North Dakota, eastern Montana, and northern Wyoming [unpublished Ph.D. thesis]: University of Minnesota, Minneapolis, Minnesota, 919 p. 
Hartman, J.H., and Young, R.A., 2010, Paleontological constraints on early Eocene landscapes and paleoenvironment of northwestern Arizona (abstract): Geological Society of America, Abstracts with Programs, v. 425, 76 p.

Huntington, K.W., Eiler, J.M., Affek, H., Guo, W., Bonifacie, M., Yeung, L.Y., Thiagarajan, N., Passey, B., Tripati, A., Daëron, M., and Came, R.E., 2009, Methods and limitations of "clumped" $\mathrm{CO}_{2}$ isotope $\left(\Delta_{47}\right)$ analysis by gas-source isotope-ratio mass spectrometry: Journal of Mass Spectrometry, v. 44, p. 1318-1329.

Huntington, K.W., Wernicke, B.P., And Eiler, J.M., 2010, The influence of climate change and uplift on Colorado Plateau paleotemperatures from carbonate "clumped isotope" thermometry: Tectonics, v. 29, TC3005 p, doi:10.1029/2009TC002449.

Keszthelyi, L., 1994, Calculated effect of vesicles on the thermal properties of cooling basaltic lava flows: Journal of Volcanology and Geothermal Research, v. 63, p. 257-266.

Ketcham, R.A., 2005, Forward and inverse modeling of low-temperature thermochronometry data: Reviews in Mineralogy and Geochemistry, v. 58, p. 275-314.

KIM, S.-T., AND O'NEIL, J.R., 1997, Equilibrium and nonequilibrium oxygen isotope effects in synthetic carbonates: Geochimica et Cosmochimica Acta, v. 61, p. 3461-3475.

Kohn, M.J., Josef, J.A., Madden, R., Kay, R., Vucetich, G., and Carlini, A.A., 2004, Climate stability across the Eocene-Oligocene transition, southern Argentina: Geology, v. 32, p. 621-624.

Lazerevs, A.N., 1972. Vibrational Spectra and the Structure of Silicates: New York, Consultants Bureau, $302 \mathrm{p}$.

Machel, H.G., Mason, R.A., Mariano, A.N., and Mucci, A., 1991, Causes and measurements of luminescence in calcite and dolomite, in Barker, C.E., and Kopp, O.C., eds., Luminescence Microscopy and Spectroscopy: Qualitative and Quantitative Applications: SEPM, Short Course 25, p. 9-26.

Machel, H.G., And BuschKuehle, B.E., 2008, Diagenesis of the Devonian SoutheskCairn Carbonate Complex, Alberta, Canada: marine cementation, burial dolomitization, thermochemical sulfate reduction, anhydritization, and squeegee fluid flow: Journal of Sedimentary Research, v. 78, p. 366-389.

Maliva, R.G., AND Dickson, J.A.D., 1992, The mechanism of skeletal aragonite neomorphism: evidence from neomorphosed mollusks from the upper Purbeck Formation (Late Jurassic-Early Cretaceous), southern England: Sedimentary Geology, v. 76, p. 221-232.

Marshall, D.J., 1988. Cathodoluminescence of Geological Materials: Boston, UnwinHyman, 146 p.

MCCREA, J.M., 1950, On the isotopic chemistry of carbonates and a paleotemperature scale: Journal of Chemical Physics, v. 18, p. 849-857.

Murase, T., And McBirney, A.R., 1973, Properties of some common igneous rocks and their melts at high temperatures: Geological Society of America Bulletin, v. 84, p. 3563-3592.

Neri, A., 1998, A local heat transfer analysis of lava cooling in the atmosphere: Application to thermal diffusion-dominated lava flows: Journal of Volcanology and Geothermal Research, v. 81, p. 215-243.

Passey, B., Levin, N.E., Cerling, T.E., Brown, F.H., And Eiler, J.M., 2010, Hightemperature environments of human evolution in East Africa based on bond ordering in paleosol carbonates: National Academy of Sciences, USA, Proceedings, v. 107, p. 11245-11249.

Patrick, M.R., Dehn, J., and Dean, K., 2004, Numerical modeling of lava flow cooling applied to the 1997 Okmok eruption: approach and analysis: Journal of Geophysical Reseach, v. 109, B03202 p.

Peters, L., 2002. ${ }^{40} \mathrm{Ar} /{ }^{39} \mathrm{Ar}$ Geochronology Results from the Mount Floyd Volcanic Field, Arizona: New Mexico Geochronology Research Laboratory, Internal Report, Document Number NMGRL-IR-281, 7 p.

PhilpotTs, A.R., 1990. Principles of Igneous and Metamorphic Petrology: New Jersey, Prentice Hall, 498 p.

Pingitore, N.E., 1982, The role of diffusion during carbonate diagenesis: Journal of Sedimentary Petrology, v. 52, p. 27-39.
Reiter, M., Mansure, A.J., and Shearer, C., 1979, Geothermal characteristics of the Colorado Plateau: Tectonophysics, v. 61, p. 183-195.

Richards, I.J., Connelly, J.B., Gregory, R.T., and Gray, D.R., 2005, The importance of diffusion, advection, and host-rock lithology on vein formation: a stable isotope study from the Paleozoic Ouachita orogenic belt, Arkansas and Oklahoma: Geological Society of America, Bulletin, v. 114, p. 1343-1355.

Schauble, E.A. Ghosh, P., and Eller, J.M., 2006, Preferential formation of ${ }^{13} \mathrm{C}-{ }^{18} \mathrm{O}$ bonds in carbonate minerals, estimated using first-principles lattice dynamics: Geochimica et Cosmochimica Acta, v. 70, p. 2510-2529.

Schmid, T.W., And Bernasconi, S.M., 2010, An automated method for "clumpedisotope" measurements on small carbonate samples: Rapid Communications in Mass Spectrometry, v. 24, p. 1955-1963.

SHARP, Z.D., AND KIRSCHNER, D.L., 1994, Quartz-calcite oxygen isotope thermometry: a calibration based on natural isotopic variations: Geochimica et Cosmochimica Acta, v. 58 , p. $4491-4501$.

Shaw, H.R., Hamilton, M.S., And Peck, D.L., 1977, Numerical analysis of lava lake cooling models: Part I, Description of the method: American Journal of Science, v. 277 , p. $384-414$.

Swart, P.K., Burns, S.J., And Leder, J.J., 1991, Fractionation of the stable isotopes of oxygen and carbon in carbon dioxide during the reaction of calcite with phosphoric acid as a function of temperature and technique: Chemical Geology, Isotope Geoscience Section, v. 86, p. 89-96.

TAFT, W.H., 1967, Modern carbonate sediments, in Chillingar, G.V., Bissell, H.J., and Fairbridge, R.W., eds., Carbonate Rocks; Origin, Occurrence, and Classification: Amsterdam, Elsevier, p. 29-50.

Tissot, B.P., Pelet, R., And Ungerer, P., 1987, Thermal history of sedimentary basins, maturation indices, and kinetics of oil and gas generation: American Association of Petroleum Geologists, Bulletin, v. 71, p. 1445-1466.

UREY, H.C., 1947, The thermodynamic properties of isotopic substances: Chemical Society of London, Journal, p. 562-581.

Wang, Z., Schauble, E.A., AND EILER, J.M., 2004, Equilibrium thermodynamics of multiply substituted isotopologues of molecular gases: Geochimica et Cosmochimica Acta, v. 68, p. 4779-4797.

Wardlaw, N., Oldershaw, A., And Stout, M.Z., 1978, Transformation of aragonite to calcite in a marine gastropod: Canadian Journal of Earth Sciences, v. 15, p. 186-196.

Wolf, R.A., Farley, K.A., and Silver, L.T., 1996, Helium diffusion and low temperature thermochronometry of apatite: Geochimica et Cosmochimica Acta, v. 60, p. $4231-4240$.

Worster, M.G., Huppert, H.E., and Sparks, R.S.J., 1993, The crystallization of lava lakes: Journal of Geophysical Reseach, v. 98, p. 15891-15901

YAPP, C.J., $2008,{ }^{18} \mathrm{O} /{ }^{16} \mathrm{O}$ and $\mathrm{D} / \mathrm{H}$ in goethite from a North American oxisol of the early Eocene climatic optimum: Geochimica et Cosmochimica Acta, v. 72, p. $5838-5851$.

YounG, R.A., 1999, Nomenclature and ages of late Cretaceous(?)-Tertiary strata in the Hualapai Plateau region, northwest Arizona (Appendix), in Billingsley, G.H. Wenrich, K.J., Huntoon, P.W., and Young, R.A., eds., 1999, Breccia-Pipe and geologic map of the southwestern part of the Hualapai Indian Reservation and vicinity, Arizona: U.S. Geological Survey, Miscellaneous Investigations Series, Map I2554, p. $21-50$

Young, R.A., 2001, The Laramide-Paleogene history of the western Grand Canyon region: setting the stage, in Young, R.A., and Spamer, E.E., eds., Colorado River Origin and Evolution, Proceedings of a Symposium Held at Grand Canyon National Park in June 2000: Grand Canyon Association, Grand Canyon, Arizona, p. 7-16.

ZaArur, S., Olack, G., ANd AfFek, H.P., in press, Paleoenvironmental implication of clumped isotopes in terrestrial land snail shells: Geochimica et Cosmochimica Acta.

Received 2 December 2010; accepted 16 April 2011. 